\title{
Philo of Alexandria: A model for early Christian 'spiritual readings' of the Scriptures
}

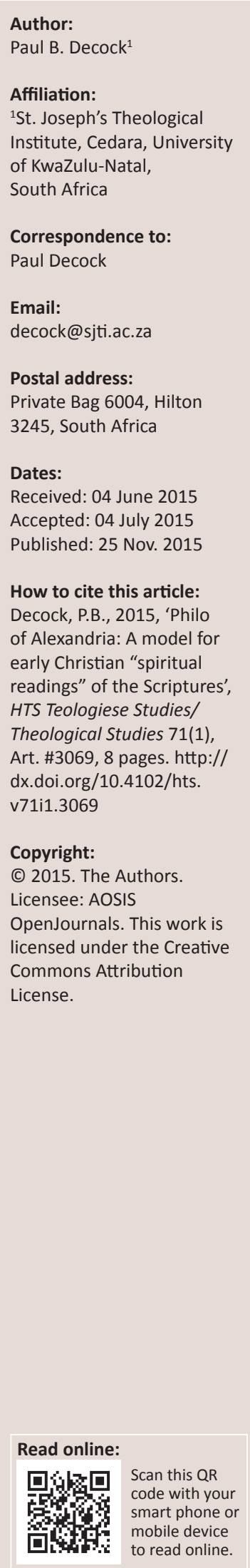

Philo of Alexandria represents a Hellenistic tradition of reading the Scriptures in which reading is seen as a spiritual exercise together with other spiritual exercises, like attention, thorough investigation of the issues, self-mastery, detachment, etcetera (see Her. 253; Leg. 3:18), which has as aim the transformation and growth of the person towards the good and happy life. Interaction with the spiritual wealth of the Greek philosophical traditions was seen as a fruitful asset and challenge. This article highlights some of the key themes of Philo's philosophical or spiritual reading of the Scriptures: the priority of God and of the health of the soul, the importance of human progress, the recognition of one's nothingness in order to know God, the necessity to choose, human effort and divine achievement, as well as harmony with God, nature and the self as the aims of the good life. Christian spiritual writers, like Origen, found in Philo's approach to the Scriptures and in his reflections on the spiritual journey a very inspiring model.

\section{Introduction}

Instead of the modern approach to go back to the meaning at the origins, the aim of the early Christian readers was to let the text become part of their context and so to let God speak through the text to the present. In those early centuries, theology had not yet been organised into separate disciplines, like biblical studies, systematic theology and spirituality. Furthermore, letting the texts speak to the present was not meant as merely imparting information or doctrines, but was understood as bringing about a transformation of the readers (cf. Jn 20:30-31). The works of Origen of Alexandria are a powerful example of how this approach was developed in 3rd-century Christianity. One can observe how he puts all the exegetical methods of his time at the service of the ultimate aim of reading, that is, the education and transformation of the readers. His model of reading the Scriptures as a spiritual exercise for the purpose of spiritual progress has continued to shape the practice and study of spirituality throughout the centuries even until today.

However, it is important to recognise how this early Christian reading of the Scriptures had firm roots in the Hellenistic Jewish tradition, and these roots deserve to be further explored particularly in the tradition best known to us in the writings of Philo. ${ }^{1}$ This Hellenistic tradition had developed a model of reading the Scriptures, which could be called a 'philosophical' reading in the sense that they explored the Scriptures in conjunction with the wisdom of Greek philosophy in search of insight and guidance towards the good life. Philo could write:

And in another passage we read, 'This is thy life, and thy length of days, to love the Lord thy God.' [Dt 30:20] This is the most admirable definition of immortal life, to be occupied by a love and affection for God unembarrassed by any connection with the flesh or with the body. (Fug. 58) ${ }^{2}$

Philo reads as a person of his time - as a committed Jew, able to draw on both the Jewish and Greek philosophical traditions. With regard to the quest for the good life, the basic interest of Hellenistic philosophy was very similar to that of the biblical Wisdom tradition - both in its earlier OT form, as well as in its later Hellenised form. One of the central questions was around how persons should conduct themselves in order to find happiness, or, as expressed in the form of the two ways, how to walk on the way to life and how to avoid the way of death (see Ps 1).

1.It is also important to be aware of the many differences between Philo and Origen. Origen was inspired by the 'philosophical approach' to the interpretation of the Scriptures, but he did not follow his views in every way. According to Thümmel (2003), for instance, Philo holds that the world will continue as it is now - it is the individual who is saved. Origen, on the other hand, expects a restoration holds that the world will continue as it is now - it is the individual who is saved. Origen, on the other hand, expects a restoration
of the whole of creation as a return to God beyond 'materiality'. In this sense we can say that the universal dimension is missing of the whole of creation as a return to God beyond 'materiality'. In this sense we can say that the universal dimension is missing
in Philo's eschatology. The apocatastasis is for Philo a return of the soul from the exile in the body to its original state (see Harl in Philo's eschatology. The apocatastasis is for Philo a return of the soul from the exile in the body to its original state (see Harl
1966:42-46; particularly note 4 on page 42). For a comprehensive survey of the older literature on Origen's relationship to Philo, see Runia (1993:157-183).

2.For the English translations, the translation as made available in BibleWorks 9 (transl. C.D. Yonge) was used. In some cases the translation was improved. 
Not unlike the biblical Wisdom tradition, Philo had no problem interacting with the wisdom literature of the surrounding peoples. In fact, Philo read the Scriptures in an intense interaction with the various Greek philosophical traditions - 'primarily Platonic, but also Stoic, Aristotelian, Pythagorean' (Runia 1993:176). His 'philosophical' interpretation of the Scriptures involved an exploration of the 'potential' of these Greek texts for his Jewish Alexandrian context. It should be understood, however, that what was called philosophy in the Greco-Roman world, and since Justin Martyr also in early Christianity, was very similar to what we now call spiritual guidance or spirituality. Philosophy was not merely a theoretical exercise, but was concerned with the practical question of the good and happy life (see Hadot 1995). Philo's philosophical reading of the Scriptures is not in view of building a system, ${ }^{3}$ but in view of letting the texts speak and contribute to the transformation of the lives of his readers. ${ }^{4}$ It is in this sense that Philo's reading must be seen as a spiritual reading, since this reading was meant to function as one of the 'exercises' by which the readers could open themselves to seek and experience the personal transformation that leads to true fulfilment and happiness. His aim was that his readers would not only know about God, but that - in reading the texts - they would experience God, ${ }^{5}$ and be moved to imitate God, to become like God, and ultimately to become one with God.

The Hellenistic Jewish exegetical tradition on which Philo was drawing, was not satisfied to briefly depict the two ways and then to challenge the readers to make a choice. They were particularly interested to read the Scriptures as symbols by which they could elaborate on the challenging journey along the path to life and to see, in the narratives of the Patriarchs, the struggles one encounters on that way to life. They were able to develop and articulate their understanding of the journey and its progress by means of the philosophical traditions of their time. Philo, just as others like 4 Maccabees, was quite convinced that the Scriptures themselves were philosophical works of the highest quality (Virt. 65). However, it should be clear that for Philo and his Alexandrian tradition to understand these philosophical texts, did not merely require technical skills (philology) and philosophical training in the sense of purely notional knowledge, but it required above all a sufficient degree of personal and existential identification with the Logos so that the interpreter can become a spiritual guide. ${ }^{6}$

\footnotetext{
3.In fact Philo is the most varied and flexible thinker of the Platonic middle realm precisely because he is not building a system but reflecting on the stories and symbols of the Scriptures' (O'Leary 2003:246). In this sense Philo is 'primarily an exegete' (Borgen 1984:259). However, he is not looking for 'ancient' meanings, but for present meanings - both literal and allegorical. According to Nikiprowetzky (1965:33-34): 'His true merit is that he has been able [...] to make of allegory - which is after all a fairly ungrateful procedure - an instrument of spiritual invention and to have used this instrument with an incredible inventiveness, a nearly divinatory feeling for analogy and symbol, a kind of visionary intensity, which transfigures with its fire the objects which it approaches and which one could only call that of a genius' (author's translation from the original French text).
}

4.It is enlightening to read Augustine's Sermo150, where he critically discusses the philosophers' search for happiness in the context of a sermon.

$5 . \ldots$ that you may not be deceived by the specious beauty of words and names, and so be separated from that real beauty which exists in the things themselves which are intended by these names' (Migr. 12).

6.Torjesen (2003) has rightly pointed out that the crucial requirement for this kind of interpretation consists in being inspired by God.
We recognise in Philo's interpretation a particular attention to the personal struggles and personal victories of human beings, but this emphasis on personal responsibility and effort is seen within the context of the whole of God's creation, and human progress is ultimately seen as the work of God. The stress on effort ( $\pi$ óvos) and the careful attention to the 'stages' of progress (лроко $\pi$ ) may give the impression that all this is mere human achievement, but nothing is further from the truth. It is God who is the beginning and end of all achievement. $^{7}$

This article will explore some of the core themes of Philo's understanding of the goal of life's journey, which is union with God. In order to understand the kind of union Philo is talking about, it is important to pay attention to some of the key challenges that the journey requires. Humans must reach the stage where they recognise their nothingness before God. This presupposes that they embark on a journey of selfemptying from inordinate attachment to the body, to sense perception, and to expressed language. Furthermore, the abandonment of their self-assuredness and the development of their receptivity are also required. This awareness of nothingness opens the path to the experience of God.

Since much of the Philonic material for this article will be taken from his De Fuga et Inventione, it will be important to appreciate that Philo was an interpreter of the Scriptures. The biblical passage he reflects upon in this work is Genesis 16:6-14 - the flight of Agar and her being found by the angel of the Lord. The treatment that precedes this one is De Congressu Eruditionis Gratia, which reflects on Genesis 16:1-6, where Sara gives Agar to Abram to raise a descendant. The commentary that follows upon De Fuga et Inventione is De Mutatione Nominum (Gn 17:1-5 and 16-22), which deals with the change of names of both Sara and Abram. As StarobinskiSafran (1970:32-33) points out, these three works form a coherent unity: the first one discusses the beginning of the journey of spiritual growth, as well as the necessity and limits of Greek general education. The third work interprets the change of names as the stage of the spiritual journey in which the soul has undergone a radical change and has been opened up to the world of God and spiritual growth. The work in the middle deals with that 'in-between stage' where the soul finds itself on the border between the attachment to the 'sensible world' and the entry into the 'intelligible world'. Philo explores the Scriptures as an inexhaustible guide to the different stages on the way to life.

\section{The priority of God and of the concern for the health of the soul}

In his critical interaction with Greek philosophical traditions, Philo's reading of the Scriptures considerably developed

7.And it is better to understand these things thus: every beginning and every end is spontaneous, that is to say, it is the work of nature and not of ourselves. For instance; what is the binnstance; what is the beginning of learning. It is plain that it is a nature in the person who is taught which is well calculated to submitted to him. Again what is the beginning of being made perfect? If we are to speak plainly without keeping anything back, it is nature. Therefore he who teaches is also indeed to effect improvement, but it is God alone; the most excellent nature of all, who is able to conduct one to supreme perfection' (Fug. 172). 
important aspects of the teaching of the Scriptures, particularly the Wisdom tradition, about the meaning of human life, viz. the superiority and priority of moral integrity over material success, the absolute importance of humility against pride, the need for radical openness to God's wisdom as opposed to being caught up in a self-centred life project, and so forth.

The scene of the dialogue between God and Salomon in 1 Kings 3 can be seen as a useful example of one such a biblical starting-point:

God said to him, 'Because you have asked this, and have not asked for yourself long life or riches, or for the life of your enemies, but have asked for yourself understanding to discern what is right, I now do according to your word. Indeed I give you a wise and discerning mind [LXX: heart]; no one like you has been before you and no one like you shall arise after you. I give you also what you have not asked, both riches and honour, so that no other king shall compare with you, all your days. If you will walk in my ways, keeping my statutes and my commandments, as your father David walked, then I will lengthen your life'. (1 Ki 3:11-14, NRSV)

What is decisive for a good life is to turn to God and to ask for a wise and discerning heart. The personal interior (heart, soul, intelligence) as the core reality of the person is where all divine blessings emerge from, provided that the heart 'realises' and 'materialises' or 'embodies' this wisdom and discernment in the physical, material realm by walking in God's ways and doing what is right in the sight of God. The heart as the core of the person is the seat of good and evil actions (Mk 7:21). What is decisive for the health of the heart is that it seeks God above all things. The saying of Jesus 'seek first for the kingdom of God and his righteousness, and all these things will be given [...] as well' (Mt 6:33) corresponds to Philo's own teaching.

Philo reads the biblical texts in this same perspective and stresses that the quality of human life depends on whether the person gives priority to the love for God and is able to recognise the relativity of the material world. A merely physical life is not life at all. It is the inner quality that is decisive; this inner quality expresses itself in the outer world, but looking merely at the outer world can be deceptive. This inner quality is often identified, in typically Greek fashion, as a life shaped by virtue:

Therefore, betaking myself for instruction to a wise woman, whose name is Consideration, I was released from my difficulty, for she taught me that some persons who are living are dead, and that some who are dead still live: she pronounced that the wicked, even if they arrive at the latest period of old age, are only dead, inasmuch as they are deprived of life according to virtue; but that the good, even if they are separated from all union with the body, live for ever, inasmuch as they have received an immortal portion. (Fug. 55)

Philo holds the principle that matter is dead, but that God is the source of life - a principle that is not really different from John 6:63, which speaks of the flesh instead of matter:

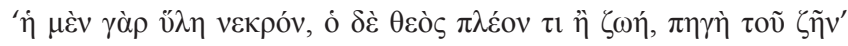
(Fug. 198).
This contrast between the spiritual and the material leads, for Philo, to the contrast between heaven and earth, where the good (power, spiritual) is associated with heaven, and the evil (weakness, material) with earth: 'But it was by all means necessary that different regions should be assigned to different things, the heaven to good things, the earth to what is evil' (Fug. 62).

The task for human beings is therefore to flee from the realm of evil and to move to the realm of goodness. However, the move is not a question of moving from one place to another, as moving away from the earth and moving towards heaven. As long as persons are in the body they will be tied to the earth. The movement, while on earth, is a transformation of the person towards a likeness to God. Philo articulates this likeness to God with a popular expression from Plato:

This, too, one of the most eminent among the men who have been admired for their wisdom has asserted, speaking in a magnificent strain in the Theaetetus, where he says, 'But it is impossible for evils to come to an end. For it is indispensable that there should always be something in opposition to God. And it is equally impossible that it should have its place in the divine regions; but it must of necessity hover around mortal nature and this place where we live; on which account we ought to endeavour to flee from this place as speedily as possible. And our flight will be a likening of ourselves to God, to the best of our power. And such a likening consists of being just and holy

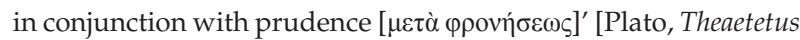
176 c]. (Fug. 63)

Philo, however, should not be seen as a one-sided spiritualist. On earth all dimensions of life have their importance - the external circumstances, the body and the soul:

... a man truly happy and blessed. When then shall this happen? When all external things prosper with me, in such a way as to tend to my abundance and to my glory. When the things relating to the body are in a favourable state, so as to give me good health and strength; and when the things relating to my soul are in a similar state, so as to enable it to enjoy the virtues. (Her. 285)

\section{The importance of progress}

In order to establish the order in one's life where the imitation of God is given first place, where the virtues overcome the vices, a person needs to set out on an arduous journey. Philo pays considerable attention to the question of progress and to the stages of growth.

In Quis rerum divinarum heres sit 293-299, Philo discusses four stages of development of the soul. The stages are summarised at the end of the section as follows, starting from the innocence of the first 7 years:

... for the first number is that into which it is not possible to receive any idea of either good or evil, since the soul is as yet destitute of all impressions; and the second is that in which we indulge in a rapid course of the passions; and the third is that in which we are healed, repelling the infections of disease, and at last ceasing to feel the evil vigour of the passions; the fourth is that in which we acquire complete and perfect health and vigour, when rejecting what is bad we appear to endeavour to 
apply to what is good, which previously was not in our power. (Her. 299)

One way of tracing this progress starts with the basic step of moving away from a way of life dominated by unregulated pleasure towards responsible social living in contrast with those who know no self-control (Fug. 28-32). In this process the active life needs to be practiced first as an intermediate stage before thinking of leading a solitary life as contemplative. This is what one can learn from the fact that the Levites were expected to serve in the liturgy until their 50th year, after which they moved to the contemplative life (Nm 4:30ff.; Fug. 37):

And at other times it is necessary that those who think themselves worthy to claim the just things of God, should first of all fulfil their human duties; for it is great folly to expect to attain to what is of greater importance, while one is unable properly to discharge what is of less consequence. First of all, therefore, be ye known for your virtue among men, that you may also become established by that which relates to God. This is the advice which perseverance gives to the man inclined to the practice of virtue $[\tau \tilde{\varphi}$

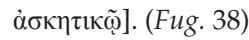

The period of active life is therefore the period during which one goes through the 'ascetic' stage - the stage of exercise and effort. At this stage one finds oneself in-between - already able to turn away from the worst, but not yet able to serve God alone:

... flee, therefore, at this present time from what is best and from what is worst. What is worst are the fabulous inventions, the unmetrical and inharmonious poems, the conceptions and persuasions which from ignorance are hard and stubborn, of which Esau is the namesake. What is best is the offering; for the race inclined to service is an offering meet for God, being consecrated to him alone in the great chief priesthood. (Fug. 42)

Jacob represents this intermediate stage, unlike Isaac who had no need of an instructor:

Accordingly Jacob both flees from Esau, and also dwells apart from his parents; for being fond of practising virtue and still labouring at it, he flees from wickedness, and yet is unable to live in company with perfect virtue so as to have no need of an instructor. (Fug. 43)

At this intermediate stage the person is invited to explore the realm of sense perception; he is invited to know himself and every part of himself and how everything is managed by the invisible mind within the person or by the mind of God within the universe:

... that is to say, learn to be acquainted with the country of the external senses; know thyself and thy own parts, and what each is, and for what end it was made, and how it is by nature calculated to energise, and who it is who moves those marvellous things, and pulls the strings, being himself invisible, in an invisible manner, whether it is the mind that is in thee, or the mind of the universe. (Fug. 46)

While involved in the active life, persons should learn to not be seduced by the vanities of life, but should rather know how to relativise all - which does not mean to reject it, but to put it to profitable personal use (Fug. 47).
Commenting on the instruction of Isaac to his son Jacob to flee to Bathouel (Gn 28:2LXX), Philo understands the place name 'Bathouel' as 'daughter of God', and therefore as God's Wisdom. After discussing the issue of Wisdom's status as both feminine and masculine, he concludes:

We say, therefore, without paying any attention to the difference here existing in the names, that wisdom, the daughter of good, is both male and a father, and that it is that which sows the seed of, and which begets learning in souls, and also education, and knowledge, and prudence, all honourable and praiseworthy things. And from this source it is that Jacob, the practiser of

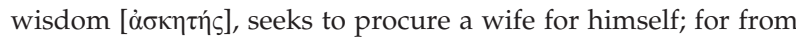
what other quarter should he seek a partner rather than from the house of wisdom? (Fug. 52)

This divine wisdom 'begets' in the person who seeks, in

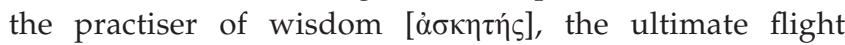
from the world, which takes place in moments of ecstasy, when the person is enabled to transcend the body, sense perception and uttered speech in order to serve the 'Only One' without distraction. This is evoked in De fuga et inventione 92 as an interpretation of Exodus 32:27 (RSV): '....and slay every man his brother [=body], and every man his companion [=sense perception], and every man his neighbour [=uttered speech $]^{\prime}$ :

Then, in regular order, reason removes to a distance and separates the uttered speech which appeared to be the nearest to it of all things, in order that speech according to the intention, ${ }^{8}$ might alone be left, free from the body, free from the entanglements of the outward senses, and free from all uttered speech; for when it is left in this manner existing in a solitary manner, it will embrace that which alone is to be embraced with purity, and without distraction. (Fug. 92)

The highest form of contact with God on earth is this silent contemplation (see Gig. 52) to go beyond the words to the realities signified (Migr. 12). For Philo, this is suggested by the story of Abraham in Genesis 22. To Isaac's question about the lamb for sacrifice, Abraham can only say: 'The Lord will provide for himself' - and what God provides is 'a ram caught'. According to Philo:

... reason is found silent and withholding its assent; for silence is the most excellent of offerings, and so is a withholding of assent to those matters of which there are not clear proofs; therefore this is all that ought to be said, 'God will provide for himself,'- he to whom all things are known, who illuminates the universe by the most brilliant of all lights, himself. But the other things are not to be said by creatures over whom great darkness is poured; but quiet is a means of safety in darkness. (Fug. 135-136)

Philo recognises that there are many stages in human progress: from the highest to the most elementary. In a discussion of the six cities of refuge mentioned in the Law of Moses (Fug. 94-105), Philo recognises a gradation that also expresses his sense of the various levels in human growth.

8.This 'speech according to intention' in Stoic philosophy is contrasted with uttered language. Words and names are pointers and we should not remain with these pointers but go to what they point to - see Migr. 12: 'that you may not be deceived by the specious beauty of words and names, and so be separated from that real beauty which exists in the things themselves which are intended by these names'. 
The first and highest place of refuge is the divine Word. The other five cities are divine powers: the first one is the creative power, the second one is the royal power or governing power, the third one is the power of mercy, the fourth one is the legislative power in the sense of commanding what we should do, and the fifth one is part of the legislative power in the sense of forbidding certain actions.

These cities are manifestations of God giving courage and hope. Running towards these cities of refuge means salvation, but among human beings there is a range of capabilities. The most capable run towards the divine Word 'which is the fountain of wisdom, in order that by drinking of that stream he may find everlasting life instead of death' (Fug. 97). Those somewhat less capable run to the creative power: 'for to him who comprehends that everything has been created, that comprehension alone, and the knowledge of the Creator, is a great acquisition of good, which immediately persuades the creature to love him who created it' (Fug. 97). Those at a lower level can run to the royal power - these are moved not by a relationship as to a father, but by the rule of a master who moderates and reprimands. The last group, after having sinned, may not be able to reach the full course of salvation, but they are offered intermediate positions in the course of the race, where they can touch God's mercy:

Again, in the case of him who is not able to reach the boundaries which have been already mentioned, in respect of their being a long way off, there are other goals appointed for them at a shorter distance, the cities namely of the necessary powers, the city of the power of the mercy, the city of the power which enjoins what is right, the city of the power which forbids what is not right. For he who is already persuaded that the Deity is not implacable, but is merciful by reason of the gentleness of his nature, then, even if he has previously sinned, subsequently repents from a hope of pardon. And he who has adopted the notion that God is a lawgiver obeys all the injunctions which as such he imposes, and so will be happy; and he who is last of all will find the last refuge, namely, the escape from evil, even though he may not be able to arrive at a participation in the more desirable good things. (Fug. 98-99) ${ }^{9}$

\section{Acceptance of human 'nothingness' in order to know God}

When persons, like Abraham, recognise their nothingness, they are enabled to approach God:

Now such a disposition of the soul, Abraham, the inspector, has deeply engraved on my memory. For, says the scripture, 'Abraham came near and said, Now have I begun to speak unto the Lord, I that am but dust and ashes;' [Gn 18:27] since then there was an opportunity given to the creature to approach the Creator, when he recognized his own nothingness. (Her. 30)

This significance of Abraham considering himself as dust and ashes can also be found in other texts of Philo:

The sacred scripture has appointed that the great High Priest, when he was about to perform the ministrations appointed by

9.On Philo's understanding of human progress towards perfection and the situation of the strugglers, see Satlow (2008:516-518). the law, should be besprinkled with water and ashes in the first place, that he might come to a remembrance of himself. For the wise Abraham also, when he went forth to converse with God, pronounced himself to be dust and ashes. (Somn. 1:214)

But, then, those who have come near to him recognize his blessedness and their own deficiency; for Abraham, when he had placed himself very near to God, immediately perceived that he was but dust and ashes [Gn 18:27]. (Deus. 1:161)

Philo interprets the traditional Delphic theme, Know Thyself, in the sense of acknowledging one's nothingness before God, which then enables one to acknowledge God. In order for this to take place, the divine eros must be allowed to take hold of the person. ${ }^{10}$ Abraham is the model to whom Philo repeatedly refers:

Of the number of these men is Abraham, who attained to great progress and improvement in the comprehension of complete knowledge; for when he knew most, then he most completely renounced himself in order to attain to the accurate knowledge of him who was the truly living God. And, indeed, this is a very natural course of events; for he who completely understands himself does also very much, because of his thorough appreciation of it, renounce the universal nothingness of the creature; and he who renounces himself learns to comprehend the living God. (Somn. 1:60)

All knowledge of God is totally dependent on God. People need to know and accept this, otherwise the 'divine word will stand aloof' - but when the mind and perception recognise their weakness, divine assistance is made available. What is required is the right reason of a soul, which is involved in spiritual 'exercises', in order to let virtue develop:

... for as long as the mind [voṽs] thinks that it attains to a firm comprehension of the objects of intellect, and the outward sense conceives that it has a similar understanding of its appropriate objects, and that it dwells amid sublime objects, the divine word stands aloof at a distance; but when each of these comes to confess its own weakness, and sets in a manner while availing itself of concealment, then immediately the right

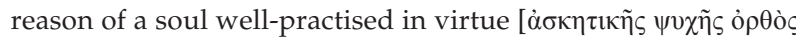
$\lambda$ óroc] comes in a welcome manner to their assistance, when they have begun to despair of their own strength, and await the aid which is invisibly coming to them from without. (Somn. $1: 119)^{11}$

\section{The responsibility to choose}

Human beings have the decisive responsibility to choose freely and willingly between the better and the worse between offering oneself wholly to God (Her. 109-111) or living for oneself and loving oneself (Her. 106-107). Human freedom consists in the ability to accept or to turn down God's offer of life. However, human freedom is that of an utterly dependent creature, because apart from God, they are

10.On this use of Know Thyself in Philo, see the work of Courcelle (1974:39-43).

11.... le point le plus important de la doctrine spirituelle de Philon est la prise de conscience et la reconnaissance par l'homme de cette nullité originelle - (Harl 1966:25, n. 3). The selected texts for this section are those pointed out by Harl in $1966: 25, \mathrm{n} .3)$. The selected
the note referred to above. 
nothing. ${ }^{12}$ The human soul has a likeness to the divine and has therefore been equipped with the gift of freedom as far as it is able to receive it. It is not condemned to necessity, but is gifted with the power to move forward, towards the development of 'spontaneous will', 'a voluntary and selfimpelling intellect':

... for that is the only quality in $\mathrm{us}^{13}$ which the Father, who created us, thought deserving of freedom; and, unloosing the bonds of necessity, he let it go unrestrained, bestowing on it that most admirable gift and most connected with himself, the power, namely, of spontaneous will, as far as he was able to receive it; for the irrational animals, in whose soul there is not that especial gift tending to freedom, namely, mind, are put under the yoke and have bridles put in their mouths, and so are given unto men to be their slaves, as servants are given to their masters. But man, who has had bestowed on him a voluntary and self-impelling intellect, and who for the most part puts forth his energies in accordance with deliberate purpose, very properly receives blame for the offenses which he designedly commits, and praise for the good actions which he intentionally performs. (Deus 47)

Human beings have the responsibility to let that gift of freedom develop within them. The more they live 'in the body', the more they will be ruled by 'necessity'. However, the more they live 'in the soul' (the divine element), the more they will be able to transcend 'necessity'

Know, then, $\mathrm{O}$ excellent man, that God alone is the truest, and most real, and genuine peace, and that every created and perishable essence is continual war. For God is something voluntary, and mortal essence is necessity. Whoever, therefore, is able to forsake war, and necessity, and creation, and destruction, and to pass over to the uncreated being, to the immortal God, to the voluntary principle, and to peace, may justly be called the abode and city of God. (Somn. 2:253)

The human soul is expected to 'pay due honour to the being who has emancipated her [...] from the authority of that grievous and severe mistress, necessity' by following 'the better' and not 'the worse':

But the soul of man, being the only one which has received from God the power of voluntary motion, and which in this respect has been made to resemble God, and being as far as possible emancipated from the authority of that grievous and severe mistress, necessity, may rightly be visited with reproach if she does not pay due honour to the being who has emancipated her. And therefore, in such a case, she will most deservedly suffer the implacable punishment denounced against slavish and ungrateful minds. (Deus 48)

It is in this sense that Philo plays with the image of the 'middle' or 'intermediate' (Gn 2:9) as the mind is placed between 'the better' and 'the worse' as two powers, drawing it in opposite directions:

12.See Winston's (Sterling 2001:135-150) discussion on the issue of freedom and determinism in Philo. Determinism is probably not a helpful way of looking at the issue. Human beings are totally dependent on God as creatures before the creator, but they are challenged to freely affirm this total dependence, which is the path to
share in the divine wisdom and freedom.

13.That quality is that of the soul that is made up of 'a purer and more excellent essence of which the divine natures were formed' (Deus 46).
It was natural therefore to place and firmly root the mind in the middle of the paradise, that is, of the universal world, having in itself faculties which draw it in contrary directions, so that it should be kept in a state of doubt when called upon to discriminate as to what it should choose and what it should avoid, since if it chose the better part it would reap immortality and glory; and if it chose the worse it would meet with reproach and death. (Plant. 45)

Choosing the better involves an exodus from one's useless self-love. This involves, as we have seen above, an exodus from the body, the external senses and uttered speech, and even more, from one's own self:

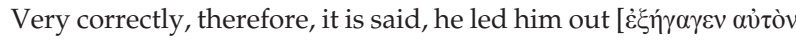
$\check{\varepsilon} \xi \omega]$ of the prison according to the body, of the caves existing in the external senses, of the sophistries displayed in deceitful speech; and beyond all this, out of himself and out of the idea that by his own self-exerted, self-implanted, and independent

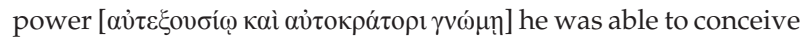
and comprehend. (Her. 85)

The descent and ascent of Rebecca to and from the fountain (Gn 24:15) is seen as 'descent' from 'arrogant haughtiness', which enables her to ascend with a full ewer of divine wisdom. This wisdom nourishes the particular sciences and the contemplative souls that are possessed by the divine eros:

These are the fountains of errors. We must now examine that of prudence. To this one it is that perseverance, that is to say, Rebecca, descends; and after she has filled up the whole vessel of her soul she goes up again, the lawgiver, most strictly in accordance with natural truth, calling her return an ascent; for whoever brings his mind to descend from over-arrogant haughtiness is raised to a great height of virtue. For Moses says, 'And having gone down to the fountain, she filled her ewer, and went up again.' This is that divine wisdom from which all the particular sciences are irrigated, and all the souls which love

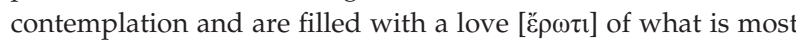
excellent. (Fug. 194-195)

It is a heavenly eros that draws the persons out of themselves towards a willing worship and service (cf. Her. 123).

\section{Human effort and progress initiated and completed by nature}

The beginning and end of the spiritual process belong to God - human effort is to be situated within the framework of God's care and is dependent on it. Philo reflects on this in terms of 'nature', the basic God-given dynamism, which can even be identified with God (see Starobinski-Safran 1970:233, n. 3 \& 4):

For as to those things with which we meet by the voluntary bounty of nature, of these we cannot find either the beginnings or the ends in ourselves as if we were the causes of them: therefore the beginning is the seed-time and the end the harvest time. And it is better to understand these things thus [Leviticus

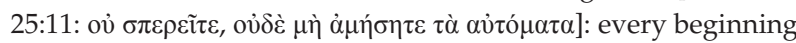
and every end is spontaneous, that is to say, it is the work of nature and not of ourselves. For instance, what is the beginning of learning? It is plain that it is a nature in the person who is 
taught which is well calculated to receive the particular subjects of meditation submitted to him. Again what is the beginning of being made perfect? If we are to speak plainly without keeping anything back, it is nature. Therefore he who teaches is also indeed to effect improvement, but it is God alone; the most excellent nature of all, who is able to conduct one to supreme perfection. (Fug. 171-172)

The creature must also be involved, even though the beginning and end are the work of God:

\begin{abstract}
The beginning of a plant is the seed, and the end is the fruit, each of them being the work, not of husbandry, but of nature. Again, of knowledge the beginning is nature, as has been shown, but the end can never reach mankind, for no man is perfect in any branch of study whatever; but it is a plain truth, that all excellence and perfection belong to one Being alone; we therefore are borne on, for the future, on the confines of beginning and end, learning, teaching, tilling the ground, working up everything else, as if we were really effecting something, that the creature also may seem to be doing something. (Her. 121)
\end{abstract}

Philo's view of human effort is complex. Effort is needed to develop one's aptitudes, otherwise they will wither away. It is a question of exercising what one has received by nature. Education and effort are the means to prevent such atrophy

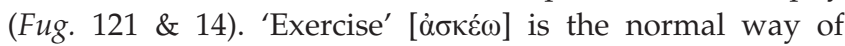
progress towards maturity, and Jacob is the model of those who struggle in view of virtue and perfection (Fug. 4: ó yoũv $\dot{\alpha} \sigma \kappa \eta \tau \eta \dot{s}$ 'I $\alpha \kappa \omega \dot{ } \beta)$. There is a need to search in order to find (see Fug. 119-123). That is also why involvement in the active life needs to precede a move towards a contemplative life (Fug. 33-38; Starobinski-Safran 1970:268-269).

And yet, 'effort is destined to abolish itself to make place for an attitude of complete receptivity, a sentiment of total confidence in God'. ${ }^{14}$ We have seen this in the 'descent' of Rebecca (Fug. 194-195), which is seen as an abandonment of 'over-arrogant haughtiness' and in the passage from Quis rerum divinarum heres sit 1:85 as a surrender of 'his own selfexerted, self-implanted, and independent power'. The effort is one of letting go - of surrendering to God and to the power of eros.

\section{The human journey as a journey towards deeper harmony with God and with nature and with the self}

The vision of the ideal 'world' is that of harmony, in which the Logos is the power that holds everything together:

\footnotetext{
... for the word of the living God being the bond of everything, as has been said before, holds all things together, and binds all the parts, and prevents them from being loosened or separated. And the particular soul, as far as it has received power, does not permit any of the parts of the body to be separated or cut off contrary to their nature; but as far as depends upon itself, it preserves everything entire, and conducts the different parts to a harmony and indissoluble union with one another. But the mind of the wise man being thoroughly purified, preserves the virtues in an
}

unbroken and unimpaired condition, having adapted their natural kindred and communion with a still more solid good will. (Fug. 112)

\section{Conclusion}

For Philo, interpretation of the Scriptures is to reflect on the divine words in order to discover the divine guidance, which will lead to a life of likeness to God. This reflection is not aimed at pinning down some definite original meaning, but at opening up the mind to receive knowledge from the Logos, which is beyond words.

It should be clear that Philo's reflection on the Scriptures is part of a set of spiritual exercises, which together aim at a process of opening the mind to the liberating, enlightening and life-giving presence of God. This is not seen as a merely notional operation in the mind, but as part of a holistic process involving body and mind. ${ }^{15}$ In this process, the person is less and less torn apart by the passions, but more and more unified by a mind, which brings about harmony with reason and nature, harmony within the person, harmony within the whole of created reality, and harmony with God. Reading - including getting to know oneself, particularly one's nothingness - is one of the exercises that leads to an abandonment of one's illusions of intellectual comprehension of God, which results in openness and greater receptivity to God beyond words.

The allegorical meanings that are developed in the course of the reading, with the help of Jewish interpretative traditions and Greek philosophical themes, are both the means and the fruit of this reflection. In these allegorical meanings, the soul is able to recognise itself as in a mirror according to the measure of its own spiritual growth (Cont. 78). Possessed by that heavenly eros, the readers are sustained on an exodus away from enslavement to the body, away from unenlightened sense perception, away from self-satisfied reliance on expressed language (written texts), and away from the conceited self towards greater receptivity, closer imitation of God, and greater harmony with God, as well as with the whole of created reality. No wonder that Christian spiritual writers like Origen found in Philo's approach to the Scriptures and in his reflections on the spiritual journey a very inspiring model.

\section{Acknowledgements}

It is a great privilege to have been invited to contribute an article as part of a tribute to Professor Pieter G.R. de Villiers. I have been associated with Pieter for many years and I have always been inspired by his work and stimulated by his friendship. Both of us have moved within biblical studies in the direction of a spiritual reading of the Scriptures. My own path started with research in the use of the Jewish Scriptures in the early Christian writings. This showed me how the modern concern about an original meaning of the text - almost in the

15. Dawson (2000:103-104) concludes: "Hence both Philo's criticism of the "excessive allegorists" and his praise of the allegorically adept Therapeutae are grounded in his own insistence on the necessary and intrinsic links between human and scriptural souls and bodies'. 
sense of information about a foreign object - was not the main concern of early Christianity or of the early medieval church.

\section{Competing interests}

The author declares that he has no financial or personal relationships that may have inappropriately influenced him in writing this article.

\section{References}

BibleWorks, 2011, BibleWorks 9, transl. C.D. Yonge, BibleWorks, Norfolk.

Borgen, P., 1984, 'Philo of Alexandria', in M.E. Stone (ed.), Jewish writings of the Second Temple Period: Apocrypha, Pseudepigrapha, Qumran sectarian writings, Philo, Josephus, pp. 233-282, Van Gorcum, Assen. (CRINT 2:2).

Courcelle, P., 1974, Connais-toi toi-même: De Socrate à Saint Bernard [Know yourself: From Socrates to Saint Bernard], Etudes Augustiniennes, Paris.

Dawson, D., 2000, 'Soul and body of texts: Philo and Origen', in J. Whitman (ed.), Interpretation and allegory: Antiquity to modern period, pp. 89-107, Brill, Leiden.

Hadot, P., 1995, Philosophy as a way of life: Spiritual exercises from Socrates to Foucault, introduction by A.I. Davidson (ed.), Blackwell, Oxford.
Harl, M., 1966, Quis rerum divinarum heres sit, Cerf, Paris. (Les Oeuvres de Philon d'Alexandrie 15).

Nikiprowetzky, V., 1965, De Decalogo: Introduction, traduction et notes, Cerf, Paris. (Les Oeuvres de Philon d'Alexandrie 23).

O'Leary, J.S., 2003, 'Logos and koinonia in Philo's De confusione linguarum', in L. Perrone, P. Bernardino \& D. Marchini (eds.), Origeniana octava: Origen and the Alexandrian tradition, paper presented at the 8th International Origen Congress, Pisa, August 27-31, 2001, pp. 245-273, University Press, Leuven. (BETL 164).

Runia, D.T., 1993, Philo in early Christian literature: A survey, Van Gorcum, Assen. (CRINT III/3).

Satlow, M.L., 2008, 'Philo on human perfection', Journal of Theological Studies 59, 500-519. http://dx.doi.org/10.1093/jts/fln089

Starobinski-Safran, E., 1970, De fuga et inventione: Intoduction, texte, traduction et commentaire, Cerf, Paris. (Les Oeuvres de Philon d'Alexandrie 17).

Sterling, G.E. (ed.), 2001, The ancestral philosophy: Hellenistic philosophy in Second Temple Judaism: Essays of David Winston, Brown Judaic Studies, Providence. (StPhilo Monographs 4).

Thümmel, H.G. 2003, 'Philon und Origenes', in L. Perrone, P. Bernardino \& D. Marchin (eds.), Origeniana octava: Origen and the Alexandrian tradition, paper presented at the 8th International Origen Congress, Pisa, August 27-31, 2001, pp. 275-286, University Press, Leuven. (BETL 164).

Torjesen, K.J., 2003, 'The Alexandrian tradition of the inspired interpreter', in L. Perrone, P. Bernardino \& D. Marchini (eds.), Origeniana octava: Origen and the Alexandrian tradition, paper presented at the 8th International Origen Congress, Pisa, August 27-31, 2001, pp. 245-273, University Press, Leuven. (BETL 164). 